\section{Storm over funding policy}

\section{London}

As part of a series of controversial cutbacks, the UK Medical Research Council (MRC) is to withdraw funds from an internationally renowned research unit in Cambridge specializing in molecular neurobiology, and is expected later this month to announce the closure of a bloodpressure research unit in Glasgow, the only one of its kind in Britain. The cutbacks mark the beginning of a tough new era for MRC funding, with a budget that is shrinking in real terms.

The cutbacks have been sharply criticized by many biomedical researchers, but are necessary, the MRC says, to generate cash for new research initiatives. With wage inflation running at 9 per cent and large sums earmarked for specific programmes such as AIDS research and the human genome initiative, the MRC is predicting a deficit in the coming year. This is rumoured to be as high as $£ 6$ million, although the MRC insists it is nearer to $£ 1$ million.

The work of each MRC research unit is reviewed every five years, and in keeping with the MRC's policy of backing individuals rather than research units per se, it is common for units to close when their directors retire. Given this perspective, the closure of the molecular neurobiology and blood-pressure units may not appear unusual, as their directors retire in 1992 and 1994 respectively. But this year, the MRC has introduced a new policy of assessing the funding of existing work in units scheduled for closure. The result has been the immediate shut-down of two of the six research groups within the molecular neurobiology unit, and the muchcriticized decision to close another unit under review, the cryobiology unit in Cambridge, against the advice of expert referees (see Nature 346, 685; 23 August 1990).

The early closure of the two research groups at the molecular neurobiology unit will save the MRC about $£ 150,000$ a year, but has dismayed unit members and other prominent neuroscientists who had assumed the MRC would stick to its normal practice of allowing units earmarked for closure to run down gradually through 'natural wastage'. Unit director Eric Barnard describes the decision as a "savage cut" - the two targeted groups contain much of the unit's vital expertise in recombinant DNA techniques, he says.

Nicholas Winterton, head of the MRC secretariat, defends the MRC's new policy of reviewing ongoing work, which he says allows a "much more focused search for savings" than simply considering new proposals. He says cuts in existing units are bound to attract more adverse publicity than refusals to fund new proposals, but says the MRC is anxious to avoid all its resources becoming tied up in long-term commitments.

In response to criticism of the closure of the cryobiology unit, Dr Dai Rees, secretary of MRC, wrote to the directors of all MRC research units explaining the new policy. The MRC had been unable to fund some 400 alpha-rated project grant applications in 1989-90, he said, making it necessary to look for "what savings we can in ongoing MRC teams to release money for new work".

But Rees's explanation has not satisfied many staff affected by the cuts. Last year,

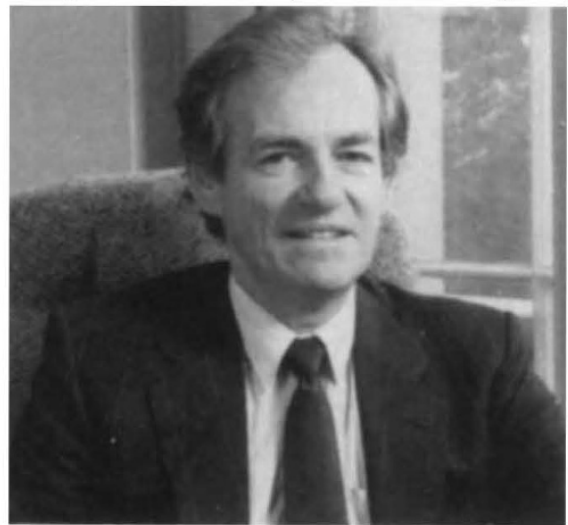

Dai Rees - savings are necessary "to release money for new work"

referees engaged in the routine review of the molecular neurobiology unit unanimously recommended that funding be continued. The decision to cut the two groups at the molecular neurobiology unit, despite their alpha ratings, was based on a recommendation from the MRC strategy committee, a subcommittee of MRC's council which examines funding priorities after peer review by the research boards. Critics say that the strategy committee has robbed the old research boards of much of their power and has failed to explain many of its recent high-level decisions or priorities. According to one research board member, Geoffrey Burnstock of University College London, the time has now come for the "relative roles of the traditional boards and the strategy committee to be clarified".

The MRC also appears to be adopting a tougher stance on public debate of its funding decisions, with one member of the molecular neurobiology unit under threat of disciplinary action over a letter published in Nature. In September, Rees told Barnard to warn his staff against engaging in any "improper criticisms of Council's policies or decisions" that may draw Rees into the public arena. Nevertheless, a letter to Nature by Rees himself (see Nature 347, 116; 6 September 1990) prompted the leader of one of the axed research groups, Penny Barnard, wife of the unit director, to respond (Nature 347,

\section{Museum with friends}

\section{London}

AN organization of 'Friends' of the Natural History Museum got off to a shaky start last Thursday amid continuing animosity between the museum's director, Neil Chalmers, and the trade union representing scientists at the museum.

The embryonic body is the brainchild of Henry Barlow, an amateur entomologist based in Malaysia. The chairman of the meeting was Jonathan Porritt, former chairman of the environmental pressure group Friends of the Earth.

Chalmers emphasized that the museum is now raising a growing proportion of its own funds, and said that $£ 9$ million out of a total budget of $£ 34$ million is generated internally. Some of this is income from the museum's development fund, whose first appeal is now just $£ 400,000$ short of its $£ 5$ million target.

Chalmers sees one function of the museum's Friends as that of providing support and argument in the "battle with the government that goes on year by year". But he also noted last week that "the first thing about friends is that they are friendly".

The appointment of an interim steering committee evoked some contrary opinions. Although Chalmers had nominated two staff members (John Peake, associate director, and Jill Nadolski, co-ordinator of the museum's membership scheme), he opposed the nomination of William Lindsey, a palaeontologist who is a member of the National Executive of the Institution of Professionals, Managers and Specialists (IPMS), which is in dispute with the museum over the effects of its corporate plan on members of staff.

But the tension at the museum appears to be abating. A third one-day strike at the Natural History Museum called for 31 October has been narrowly averted. Most of the cuts in research posts outlined in the corporate plan have now been made, and the number of enforced redundancies is likely to be fewer than ten.

Henry Gee

$324 ; 27$ September 1990), calling on the $\mathrm{MRC}$ to explain the financial position underlying the need to make such drastic cuts in an established unit at short notice.

In a confidential letter to Eric Barnard, Rees described this letter as "sufficiently misleading as to be damaging to the Council", and insisted that action should be taken over what he termed a "serious breach of discipline". Barnard has refused to discipline his wife, and is waiting for Rees's response. Winterton says that a clause in MRC staff contracts forbids public comment against MRC policy, but maintains that the MRC is "a good deal more relaxed" in its attitude to public dissent than most employers

David Concar \& Peter Aldhous 